氏巨脾症等アリ。

余八最近星野䧗物二於テ突然鼻出血 7 以テ發病 シ臨林上出血性舅茸/所見 7 呈スル 15 歲女生

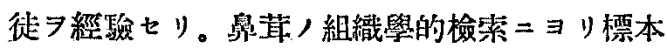

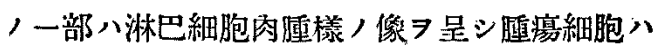
大小不同，圆形狀細胞 ニシテ (Polymorphie) 其內方ニ八圆形ノ大ナル細胞厂リ。外方二八絬 締織細胞 =似タル細長且ツ大ナル細胞厂リ。他 八一部ニ於テハ淋巴組織ノ睤殖顯著ニシテ淋巴 商芽腫，像 7 呈ス。當科入院時，局所所見八左 側鼻腔內二充满スル腫暍 側 $=$ 彎曲 $ᄌ$ 。左眼球突出，左方慜見時二重視 7 訴?。胸部及ビ凌部，諸臟器二異常ナっ全身所 見トシテ舉グべキモノナシ。激烈ナル鼻出血反 㠅シ篇 $=$ 左側外頸動脈 7 結禁ス。血液所見トン テ高度ノ筫血，赤血球減少：白血球数正常，病 的白血球出現. 相對的淋巴球增多厂ッ。出血性 素因 7 認 $\times$ ス。其後漱次胸骨疼痛. 膰臟肥大.

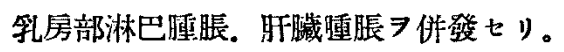

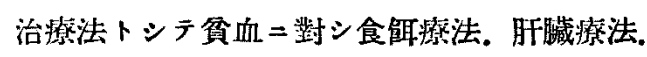

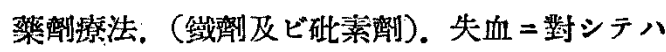
輸血. 脾睡並 $=$ 淋巴腺腫等二對シテハ「レント ダン」線療法ヨ行ヒタルモ入院後 115 日目 $=$ ハ 逐二死ノ轉歸ヨトル。

余ハ本症例 =於テ剖检 許サレザリシモ全身所 見，血液所見，骨䯕穿刺所見，局所所見並二鼻

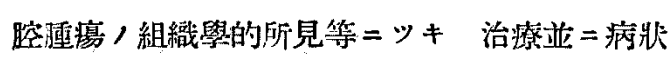
經過二聊カ所見ヨ得タレバ「ロイコーゼ」. 淋巴 肉董症. 惡性肉芽腫症二就テ考案セントス。

12. (イ)蒛科用「ブローチリーマ」脫落防 止器 (口) 扁剔用周圆組織挫减

切斷鉜子 香宗我部 喜(裴 楬)

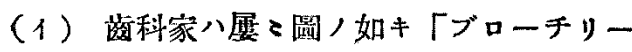

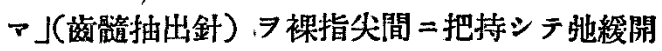
口七ル口貯內二作業セル篇メ. 誤ツテ之氣.

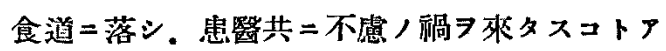
ルニ鑑え，之ヨ考案作製セシメタリ。

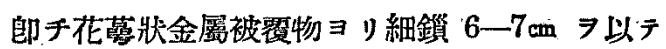
ひ狀指環＝連絡セシメ．任意ノ「ブローチリー マ」頭部 着ケテ弛緩開口七ルロ中二操作スル封八 若シ 取扱者ノ指尖ヨリ脫離シテモ。氣・食道! 異物 トナルコトナシ。 余ハ之ヨ苳科家二推獎セシトス。

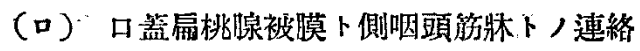

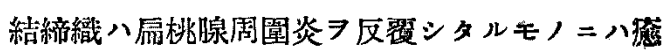
着强靶ニシテ剂離/際出血多シ．之等ノ粗密種 種ナル連絡結締織 7 鈍的二起子 7 以テ制離スル ヨリモ. 先ヅ鍃子・ヨ以テ把握シ。一旦挫隇シテ 其中間 限シ. 血液喀出，煩モ少ク。手衔時閒 7 短縮シ 得ベシ。

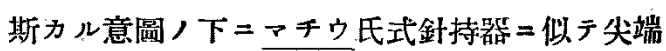
ノ曲リ。腹膜鋪子ノ如キモノフ造りタリ。而シ テ相對スル挫減面，中央 $=$ 满 $\ni$ 設分，其溝內 7 彈條刃ガ把柄ノ把握ニヨリテ進退シ。挫隇シタ ル結締織/中間 7 切斷スル機棈トナセリ。

\section{3. 組織染色二传儿扁桃腺內細菌，}

研究大西克 保(杂梨) 嚴格ナル適應症制定,下 $=$ 被膜外全剔出 $\Rightarrow$ 行 ヒテ得タルロ蓋确桃腺 150 箅及ビ咽頭扁桃㟫 30有餘简 =於テ組織染色法: $=$ リ組織內外，細 菌フ检少シタルモ。細菌染色ニハ「パラフィン」 包埋，切片二於ラ「リチオンカルにン」ドク トリアブラウ」重染色法フ用七. 組織/病理悬 的檢索ニハ「ヘアトキシリン.エオジン」重染色 